\title{
RESEARCHPAPER
}

\section{Genetic diversity studies in whaet (Triticum aestivum L.) based on cluster analysis}

\author{
M. S. KAMBLE ${ }^{1}$, S. P. SAWANT ${ }^{1}$ AND R. M. PAWAR ${ }^{2}$ \\ ${ }^{1}$ Division of Agricultural Botany, College of Agriculture, KOLHAPUR (M.S.) INDIA \\ (Email: atharv_2005@rediffmail.com) \\ ${ }^{2}$ Department of Agricultural Botany, BharatiVidyapeeth's Loknete Mohanrao Kadam College of Agriculture, \\ Kadegaon, SANGLI (M.S.) INDIA (Email: ranveer_1972@ rediffmail.com) \\ Email : murlikamble5@gmail.com
}

Article Info : Received : 12.11.2016; Revised : 16.03.2017; Accepted : 26.03 .2017

The significant differences between 32 genotypes of wheat for all the characters were observed. Genotypes were grouped into six clusters with cluster I having maximum genotypes (18) followed by cluster III and clusters II, clusters IV and VI were monogenotypic. Maximum inter-cluster distance was recorded between cluster V and VI (860.24) and maximum intra-cluster distance was recorded in cluster III (130.18). Cluster III registered maximum cluster mean values for grain yield and important yield contributing characters like ear head length, spikelets per spike, tillers per running meter, grains per spike, 1000 grain weight, hectolitre weight and protein content. The highest contribution towards genetic diversity was contributed by plant height followed by protein content and 1000 grain weight. Therefore, for hybridization genotypes from cluster V and VI should be selected for obtaining desired recombinants in the segregating generations.

Key words : Genetic diversity, Clusters, Soybean

How to cite this paper : Kamble, M.S., Sawant, S.P. and Pawar, R.M. (2017). Genetic diversity studies in whaet (Triticum aestivum L.) based on cluster analysis. Asian J. Bio. Sci., 12 (1) : 32-35.DOI : 10.15740/HAS/AJBS/12.1/32-35. 